\title{
Penentuan Umur Manusia menggunakan Rongga Pulpa Gigi Pramolar Pertama melalui Pendekatan Cameriere
}

\author{
(Human Age Estimation using First Premolar Dental Pulp Cavity via Cameriere's Approach)
}

Rus Dina Rus Din, Siti Nur ZAHIDAH ZAHARI, RoHAYA MEGAT ABDUL WAHAB, ZAIDAH ZAINAL ARIFFIN, LIEW YI YING \& SHAHRUL HiSHAM ZAINAL ARIFFIN*

\section{ABSTRAK}

Pemendapan dentin sekunder akan menyebabkan pengecilan rongga pulpa gigi selari dengan peningkatan umur seseorang. Tujuan kajian ini dijalankan adalah untuk mengetahui hubungan antara saiz rongga pulpa gigi dengan umur individu menggunakan nisbah kawasan pulpa/kawasan gigi (PTR) berdasarkan pendekatan Cameriere pada populasi Malaysia. Kajian ini melibatkan sebanyak 168 sampel gigi; 136 sampel untuk menjana formula manakala 32 sampel lagi untuk ujian ketepatan formula. Imej radiograf dua dimensi bagi 136 gigi pramolar pertama daripada populasi di Malaysia digunakan dalam kajian ini. Pengukuran gigi adalah berdasarkan kaedah Cameriere iaitu mengukur nisbah kawasan pulpa kepada kawasan keseluruhan gigi (PTR). Analisis statistik Pearson dilakukan bagi melihat hubungan antara saiz rongga pulpa dengan umur individu manakala analisis regresi linear dilakukan bagi menjana formula pengiraan untuk menganggar umur individu. Analisis korelasi Pearson mendapati terdapat hubungan negatif antara saiz rongga pulpa dengan umur (koefisien korelasi:-0.608 hingga -0.699) menunjukkan saiz rongga pulpa akan bertambah kecil apabila umur semakin meningkat. Formula pengiraan yang dijana mendapati nilai $R^{2}$ antara 0.37 hingga 0.488 dengan nilai S.E.E. 3.329 hingga 4.413 tahun. Sebanyak 32 sampel gigi pramolar pertama baru yang dipilih secara rawak digunakan untuk menguji ketepatan formula pengiraaan. Julat purata perbezaan antara umur sebenar individu dengan umur yang dianggarkan menggunakan formula pengiraan adalah 1.670 hingga 3.316 tahun. Formula pengiraan yang dijana berpotensi untuk digunakan bagi menganggar umur individu dalam kes forensik serta kajian arkeologi.

Kata kunci: Nisbah kawasan pulpa kepada kawasan gigi (PTR); pemendapan dentin sekunder; penganggaran umur

\section{ABSTRACT}

Apposition of secondary dentine can cause the decrease in pulp cavity size as the age of an individual increases. The purpose of this study was to examine the relationship between the pulp cavity size and the age of an individual using pulp/tooth area ratio (PTR) based on Cameriere's method of Malaysian population. This study involved 168 samples with 136 samples to generate formula and 32 samples for validity test. Two-dimensional radiographs of 136 first premolar samples from Malaysian populations were used in this study. The teeth measurement was based on Cameriere's method where the ratio of pulp area to the overall tooth area PTR (pulp/tooth area ratio). Pearson statistical analysis was carried out to examine the relationship between pulp cavity size and individual's age while linear regression analysis was done to develop formula for age estimation. Pearson correlation analysis shows that there is negative correlation between pulp cavity size and individual's age (correlation coefficient: -0.608 to -0.699); an indication that the size of pulp cavity become smaller when the age increase. The $R^{2}$ value based on the formula ranged between 0.37 and 0.488 and S.E.E. ranging from 3.329 to 4.413 years. A total of 32 randomly selected first premolar samples were used to validate the accuracy of the formulas generated. The mean difference between the real age and the estimated age ranged from 1.670 years to 3.316 years. The generated formula can be potentially used to estimate individual's age in forensic cases and archaeological researches.

Keywords: Age estimation; apposition of secondary dentine; pulp/tooth area ratio (PTR)

\section{PENDAHULUAN}

Anggaran umur individu adalah elemen penentu yang penting dalam bidang forensik terutama semasa proses pengecaman mangsa, jenayah dan kemalangan (Sakhdari et al.2015). Gigi menjadi pilihan utama dalam menganggar umur individu kerana gigi didapati lebih tahan lama terhadap proses degradasi serta tidak mudah musnah akibat faktor persekitaran (Cunha et al. 2009). Selain itu, pendekatan genetik molekul juga boleh dilakukan untuk penentuan jantina melibatkan kromosom seks (Shahrul Hisham et al. 2009) dan filogenetik yang melibatkan DNA mitokondria (Sahidan et al. 2014). Penentuan kaum etnik Kadazan Dusun dari kepulauan Borneo boleh ditentukan melalui pendekatan Cephalometric dan Malocclusion yang melibatkan bahagian tengkorak manusia (Rohaya et al.2013). 
Dalam kajian ini, gigi pramolar pertama digunakan untuk penentuan umur individu. Tahap pertumbuhan gigi boleh menentukan umur seseorang individu (El-Bakary et al. 2010). Kajian oleh Shahrul Hisham et al. (2010) telah mengenal pasti profil aktiviti penanda biologi laktat dehidrogenase, asid fosfatase rintang tartrat dan alkalin fosfatase dalam pergerakan gigi semasa rawatan orthodontik. Pergerakan dan pertumbuhan gigi ini pada peringkat sel melibatkan pembezaan sel stem seperti sel stem pulpa gigi (Shabnam et al. 2014) dan sel stem darah periferi (Ruzanna et al. 2012) untuk membentuk sel matang yang baru. Walau bagaimanapun, apabila seseorang individu meningkat dewasa ( $\sim 21$ tahun ke atas), pertumbuhan dan perkembangan gigi telah lengkap dan terhenti (Cunha et al. 2009). Oleh itu, tahap pertumbuhan gigi tidak boleh lagi digunakan untuk menganggar umur individu dewasa yang berusia 21 tahun ke atas. Umur individu dewasa boleh ditentukan melalui proses penuaan gigi seperti atrisi gigi, hakisan gigi, penyakit periodontal, perubahan warna gigi dan pemendapan dentin sekunder pada dinding rongga pulpa (Jeevan et al. 2011). Walau bagaimanapun, apabila melibatkan persekitaran yang berlainan, faktor-faktor seperti atrisi gigi, hakisan gigi, penyakit periodontal dan perubahan warna gigi tidak dapat menganggar umur individu dewasa dengan tepat.

Rongga pulpa gigi didapati akan menjadi semakin kecil dengan peningkatan umur seseorang individu akibat daripada pemendapan dentin sekunder pada dinding rongga pulpa gigi (Limdiwala \& Shah 2013). Pemendapan dentin sekunder terjadi akibat daripada hasil rembesan matriks daripada odontoblas secara berterusan bermula selepas pembentukan lengkap dentin primer. Pemendapan dentin sekunder akan menyebabkan pengecilan pada saiz rongga pulpa gigi. Oleh itu, pemendapan dentin sekunder berpotensi untuk dijadikan penanda dalam menganggar umur individu menggunakan pendekatan saiz rongga pulpa gigi kerana rongga pulpa gigi akan mengecil selari dengan peningkatan umur seseorang dan ruang ini boleh diukur menggunakan imej radiograf(Erbudak et al. 2012). Pendekatan ini telah dilakukan oleh Cameriere et al. (2007) untuk mengenal pasti hubungan pemendapan dentin sekunder dalam penganggaran umur dengan menggunakan imej radiograf.

Sampel gigi yang lengkap dalam kebanyakan kes forensik adalah sukar untuk dijumpai dan pada sesetengah kes hanya akan terdapat sebatang gigi sahaja yang diperoleh. Selain itu, sampel gigi yang tidak lengkap juga kerap dijumpai di dalam kajian yang melibatkan sampel arkeologi (Rus Dina 2014; Verma et al. 2014). Oleh itu, pengukuran rongga pulpa gigi merupakan pendekatan yang sesuai bagi kebanyakan kes forensik dan arkeologi dalam menganggar umur kerana ia boleh dilakukan pada sampel gigi tunggal tanpa memerlukan struktur gigi yang lengkap. Pendekatan radiografi memainkan peranan yang penting dalam kajian bagi menentukan umur individu. Radiografi merupakan teknik yang mudah dan tidak membawa kerosakan kepada sampel gigi serta proses pengulangan pengimejan boleh dilakukan (Panchbhai 2011). Selain itu, radiograf juga boleh dijalankan terhadap individu pada setiap 6 bulan dengan pendedahan radiasi yang minimal (Jeevan et al. 2011). Terdapat pelbagai jenis radiograf yang boleh digunakan dalam menganggar umur individu iaitu radiograf periapikal, radiograf ortho-CT, radiograf micro-CT dan lain-lain (Panchbhai 2011). Kajian oleh Cameriere et al. (2007) telah menentukan nilai PTR (nisbah kawasan pulpa kepada kawasan gigi) gigi kanin dengan menggunakan radiograf periapikal. Aboshi et al. (2000) pula menggunakan radiograf ortho-CT dalam menganalisis keratan rentas imej pulpa akar gigi manakala Agematsu et al. (2010) menggunakan pendekatan radiograf micro-CT dengan perisian analisis isipadu untuk mengukur nisbah isipadu rongga pulpa terhadap pelbagai jenis gigi. Walau bagaimanapun, kesemua kajian yang telah dilakukan ini hanya melibatkan populasi Eropah dan Jepun.

Kajian anggaran umur menggunakan gigi kanin bagi populasi India melalui teknik Cameriere yang dijalankan oleh Jeevan et al. (2011) telah menerbitkan formula pengiraan yang berbeza dengan kajian Cameriere et al. (2007) yang menggunakan gigi kanin pada populasi Kaukasia, Eropah. Perbezaan ini menunjukkan wujudnya perbezaan formula yang akan dijana jika menggunakan populasi yang berlainan. Maka, kajian ini adalah bertujuan untuk menentukan hubungan antara saiz rongga pulpa gigi pramolar pertama dengan umur individu berdasarkan PTR serta menjana formula yang khusus berdasarkan populasi penduduk Malaysia untuk menganggar umur individu menggunakan pendekatan Cameriere et al. (2007). Selain itu, ujian melibatkan sampel gigi yang dipilih secara rawak juga dilakukan bagi menentukan ketepatan formula pengiraan yang dijana dalam menganggar umur individu berdasarkan kepada populasi penduduk Malaysia.

\section{BAHAN DAN KAEDAH}

\section{SAMPEL GIGI PRAMOLAR PERTAMA}

Sampel ditentukan berdasarkan pada pendekatan persampelan mudah yang diperoleh hasil cabutan gigi individu yang menjalani rawatan ortodontik. Imej radiograf dua dimensi bagi 168 sampel gigi pramolar pertama telah digunakan dalam kajian ini. Kesemua gigi pramolar pertama diperoleh dari Klinik Pergigian UKM serta klinik pergigian swasta. Sampel gigi pramalor pertama dipilih daripada individu sihat, tiada masalah pergigian seperti karies gigi, penyakit periodontal, protesis dan atrisi gigi. Gigi pramolar pertama yang bebas daripada sebarang keabnormalan terhadap morfologi pembentukan gigi dan akar gigi telah dipilih sebagai sampel untuk memastikan ketepatan data yang dianalisis.

Pesakit ortodontik hanya melibatkan julat umur 10 hingga 39 tahun. Kumpulan umur seterusnya dibahagikan kepada tiga kumpulan yang terdiri daripada kumpulan remaja (10-19 tahun), manakala dewasa dibahagikan kepada dua kumpulan iaitu awal dewasa bagi usia dua puluhan (20-29 tahun) dan dewasa pada usia tiga puluhan (30-39 tahun). Sebanyak 136 imej radiograf daripada 
sampel gigi yang diperoleh digunakan untuk pembinaan formula pengiraan bagi menganggar umur seseorang individu. Selain itu, sebanyak 32 lagi sampel gigi pramolar pertama dipilih secara rawak daripada jumlah keseluruhan 168 sampel gigi pramolar pertama yang diperoleh digunakan untuk menguji ketepatan formula yang dijana. Cadangan penyelidikan etika telah disediakan dan mendapat kelulusan bagi menjalankan penyelidikan dengan nombor rujukan UKM PPI/111/8/JEP-2018-155 sebelum pengumpulan sampel gigi dilakukan.

Kesemua gigi pramolar pertama diperoleh dari Klinik Pergigian UKM dan klinik pergigian swasta di sekitar Selangor dan Negeri Sembilan. Dokumentasi sampel gigi dilakukan dengan mengambil maklumat nama, tarikh lahir, tarikh cabutan gigi, jantina, bangsa dan jenis gigi bagi setiap individu. Selepas cabutan, sampel gigi dibersihkan dengan menggunakan pencuci aseptik dan dikeringkan. Seterusnya, sampel gigi diimbas bagi memperoleh imej digital radiograf dua dimensi untuk tujuan pengukuran rongga pulpa gigi. Pengimejan gigi pramolar pertama ini dilakukan menggunakan mesin pengimbas CanoScan 8800F (Canon, USA) melalui pendekatan paralel.

Terdapat empat jenis batang gigi pramolar pertama pada setiap individu iaitu dua batang gigi yang terletak pada arkus maksila manakala dua batang gigi lagi terletak pada arkus mandibel. Pramolar pertama pada arkus maksila dikenali sebagai gigi 14 dan 24, manakala gigi 34 dan 44 pula adalah gigi pramolar pertama yang terletak pada arkus mandibel. Sistem pengkelasan ini adalah mengikut kaedah pengkelasan Federation Dentaire Internationale (FDI) (Rajah 1).

\section{PENGUKURAN RONGGA PULPA GIGI}

Pengukuran rongga pulpa gigi dilakukan berdasarkan teknik pengukuran Cameriere et al. (2007) dengan nilai PTR (nisbah kawasan rongga pulpa gigi dan seluruh kawasan gigi) diukur menggunakan perisian Image $J$ (Rajah 2). Pengukuran gigi dilakukan sebanyak tiga kali oleh pemeriksa yang sama pada waktu yang berlainan dalam jangka masa 3 bulan. Nilai PTR yang dijana merupakan nilai purata bagi tiga bacaan yang diukur.

\section{ANALISIS STATISTIK}

Data pengukuran gigi pramolar pertama berdasarkan kaedah Cameriere dianalisis menggunakan perisian statistik Minitab 18. Analisis kebolehpercayaan untuk kesemua 168 sampel dilakukan bagi menentukan keselarasan pengukuran yang dijalankan. Seterusnya, ujian normaliti Ryan Joiner dilakukan bagi mengetahui sama ada data pengukuran serta umur tertabur secara normal atau tidak $(p>0.05)$. Kemudian, data pengukuran dianalisis menggunakan ujian korelasi Pearson bagi mengetahui hubungan antara saiz rongga pulpa gigi (berdasarkan PTR) dengan umur individu. Dalam kajian ini, hubungan ini dilihat berdasarkan pada tiga kombinasi gigi pramolar iaitu gigi pramolar pertama pada arkus maksila (kombinasi 14 dan 24), arkus mandibel (kombinasi 34 dan 44) dan kesemua gigi pramolar (kombinasi 14, 24, 34, dan 44).

Seterusnya, analisis menggunakan pendekatan stepwise-regresi linear dilakukan terhadap imej radiograf daripada 136 sampel gigi pramolar pertama bagi menjana formula pengiraan untuk menganggar umur individu berdasarkan nisbah PTR. Terdapat tiga formula pengiraan yang dijana masing- masing mewakili gigi pramolar pertama pada arkus maksila, arkus mandibel serta gabungan semua gigi pramolar pertama. Kemudian, 32 sampel gigi pramolar pertama dipilih secara rawak untuk menguji ketepatan formula pengiraan yang telah dijanakan dalam menganggar umur individu. Seterusnya purata perbezaan antara umur sebenar individu dengan umur yang dianggarkan berdasarkan formula pengiraan yang dijana dilakukan untuk mengenal pasti formula dan kumpulan kombinasi gigi pramolar yang paling tepat dalam penganggaran umur.

\section{HASIL DAN PERBINCANGAN}

\section{PENGUKURAN RONGGA PULPA GIGI}

Gigi pramolar pertama yang sihat mudah diperoleh daripada pesakit ortodontik kerana ia sering dijadikan pilihan utama untuk dicabut semasa proses rawatan ortodontik. Pengukuran keluasan rongga pulpa gigi

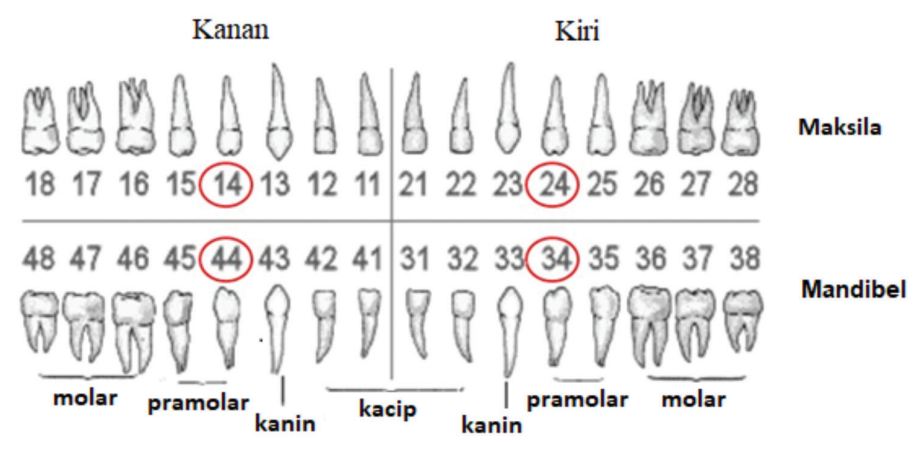

RAJAH 1. Tatatanda FDI untuk gigi pramolar pertama kekal. Sampel gigi pramolar pertama 14 (bahagian kanan atas) dan 24 (bahagian kiri atas) yang terletak pada arkus maksila, manakala 34 (bahagian kiri bawah) dan 44 (bahagian kanan bawah) pada arkus mandibel 
pramolar pertama telah dilakukan dengan menggunakan perisian Image $J$ (Rajah 2). Image $J$ merupakan perisian pemprosesan imej saintifik yang boleh memapar, mengedit, menganalisis, memproses, menyimpan dan mencetak imej. Kajian ini melibatkan seorang pemeriksa sahaja. Oleh itu, pengukuran dilakukan sebanyak tiga kali pada waktu yang berlainan bagi memastikan data yang diambil adalah konsisten. Saiz gigi pramolar pertama yang lebih besar membantu mengurangkan ralat dalam pengukuran saiz berbanding dengan gigi kanin.

Teknik Paralel telah digunakan dalam pendekatan radiografi periapikal serta merupakan pendekatan yang terbaik dalam menghasilkan imej radiograf gigi pramolar. Teknik ini melibatkan sinar-X yang dipancarkan bersudut tepat dengan kepanjangan gigi pramolar manakala filem penerima pula berada di bahagian belakang pada kedudukan yang selari dengan gigi sepanjang enamel hingga akar gigi. Pendekatan ini dapat menghasilkan sudut pancaran yang lebih tepat, imej yang lebih jelas dan mengurangkan kesan 'distortion' dalam pembesaran piawai.

Pengukuran keluasan rongga pulpa gigi pramolar pertama telah dilakukan dan nilai Cronbach's alpha bagi kesemua pengukuran berdasarkan teknik Cameriere ialah 0.9909. Nilai Cronbach's alpha yang lebih daripada 0.9 menunjukkan pengukuran yang dilakukan adalah konsisten (Tavakol \& Dennick 2011). Oleh itu, keputusan ini menunjukkan bahawa teknik pengukuran rongga pulpa gigi melalui pendekatan Cameriere sentiasa sama, walaupun jika diulang oleh pemeriksa yang sama atau berlainan. Gigi pramolar pertama yang digunakan sebagai sampel kajian perlu bebas daripada sebarang keabnormalan terhadap pembentukan morfologi rongga pulpa gigi bagi memastikan ketepatan data dan analisis. Keabnormalan terhadap pembentukan morfologi gigi adalah disebabkan oleh pembentukan karies gigi serta penyakit periodontal (Chandramala 2009).

Kompleks dentin pulpa akan dipengaruhi oleh pelbagai faktor fisiologi dan patologi seperti karies dan rawatan pembaikpulihan morfologi gigi (Arora et al 2016). Dentin tertiari terbentuk hasil daripada tindak balas pertahanan badan terhadap rangsangan luar seperti bakteria atau patogen yang menyebabkan penyakit gigi (Mjör 2009). Dentin tertiari terbentuk daripada odontoblas sekunder yang telah mengalami perbezaan sel selepas odontoblas primer dimusnahkan oleh patogen atau bakteria. Pembentukan dentin tertiari akan menyebabkan pengecilan terhadap rongga pulpa gigi. Hasilnya akan berlaku ketidaktepatan dalam data pengukuran dan seterusnya penganggaran umur individu.

\section{UJIAN NORMALITI BAGI PENGUKURAN RONGGA PULPA GIGI}

Ujian normaliti Ryan-Joiner dilakukan bagi menentukan taburan data pengukuran. Analisis ujian normaliti RyanJoiner menunjukkan data pengukuran yang diperoleh mempunyai taburan yang tidak normal. Kumpulan 10-19 tahun (remaja) mempunyai jumlah gigi yang paling banyak iaitu 80 batang gigi pramolar pertama diikuti dengan kumpulan awal dewasa pada julat umur 20-29 tahun (49 batang gigi) manakala kumpulan dewasa umur (30-39 tahun) mempunyai jumlah gigi yang paling sedikit iaitu 7 batang gigi pramolar pertama (Jadual 1). Kumpulan umur 10-19 tahun diikuti 20-29 tahun mempunyai bilangan sampel gigi yang paling banyak kerana lebih ramai golongan muda menjalani rawatan ortodontik berbanding golongan yang lebih tua (30-39 tahun). Jadual 1 menunjukkan taburan jumlah dan jenis gigi pramolar pertama yang diperoleh daripada kumpulan umur individu yang berbeza.

\section{ANALISIS KORELASI Pearson}

Ujian korelasi Pearson dilakukan bagi mengetahui hubungan antara umur sebenar individu dengan saiz rongga pulpa gigi pramolar pertama adalah berdasarkan kepada pengukuran Cameriere. Dalam kajian ini, ujian korelasi Pearson menunjukkan terdapat hubungan yang

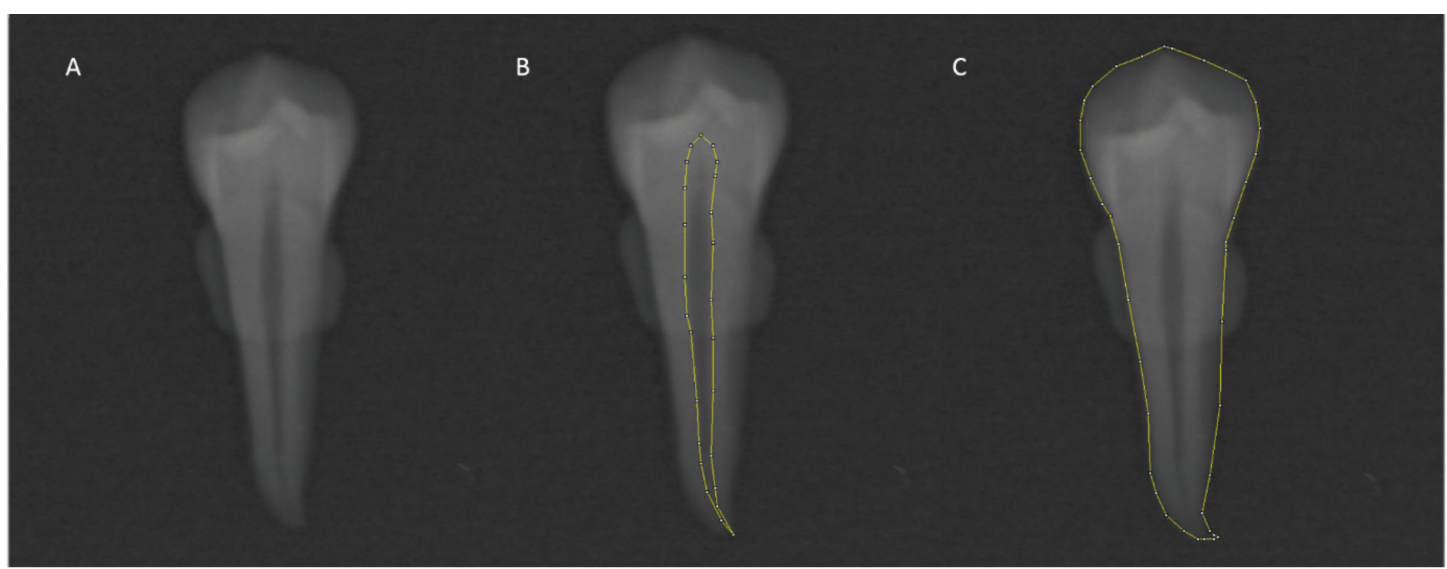

RAJAH2. Imej radiograf gigi kiri pramolar mandibel (34) yang diukur luas pulpa dan gigi dengan alat garis: A merupakan imej gigi 34, B adalah garis yang dibina untuk penentuan luas pulpa manakala $\mathrm{C}$ adalah untuk luas gigi. Pembesaran sebenar 300x 
JADUAL 1. Taburan jumlah gigi pramolar pertama mengikut kumpulan umur dan jenis pramolar pertama

\begin{tabular}{lcccc}
\hline \multirow{2}{*}{ Jenis pramolar } & \multicolumn{3}{c}{ Kumpulan umur (Tahun) } & \multirow{2}{*}{ Jumlah (batang) } \\
\cline { 2 - 4 } & $10-19$ & $20-29$ & $30-39$ & 79 \\
Maksila & 42 & 35 & 2 & 57 \\
Mandibel & 38 & 14 & 5 & 136 \\
Maksila+Mandibel & 80 & 49 & 7 & \\
\hline
\end{tabular}

Maksila: Terdiri daripada jenis 14 dan 24, Mandibel: Terdiri daripada jenis 34 dan 44, Maksila dan Mandibel: Terdiri daripada jenis $14,24,34$ dan 44

negatif antara umur individu dengan saiz rongga pulpa gigi pramolar pertama yang diukur (Jadual 2). Nilai koefisien korelasi (r) adalah antara -0.608 hingga $-0.699(p<0.05)$. Hubungan yang negatif ini menunjukkan semakin meningkat usia seseorang individu maka semakin kecil saiz rongga pulpa gigi. Dentin sekunder akan menjadi semakin tebal menyebabkan saiz rongga pulpa gigi menjadi semakin kecil setara dengan peningkatan umur seseorang (Erbudak et al. 2012; Limdiwala \& Shah 2013).

Dalam kajian ini, data pengukuran PTR bagi gigi pramolar pertama pada arkus mandibel mempunyai korelasi yang tertinggi dengan umur sebenar individu iaitu $r=-0.699$; gigi pramolar pertama pada arkus maksila pula adalah $r=-0.608$ sama seperti kombinasi gigi maksila dan mandibel juga mempunyai nilai korelasi koefisien yang paling rendah iaitu $r=-0.608$. Analisis korelasi Pearson antara umur dengan PTR bagi gigi kanin maksila juga telah dilakukan oleh Jeevan et al. (2011) dalam menganggar umur populasi penduduk di India menggunakan gigi kanin (13, 23, 33 dan 43) berdasarkan pendekatan Cameriere. Nilai koefisien korelasi (r) hasil kajian Jeevan et al. (2011) adalah - 0.807 bagi gigi kanin pada arkus maksila manakala gigi kanin mandibel adalah -0.745. Nilai koefisien korelasi Pearson (r) bagi kedua-dua gigi kanin maksila dan mandibel pula adalah -0.995. Ini menunjukkan bahawa walaupun pendekatan pengukuran yang sama digunakan, nilai koefisien korelasi bagi kedua-dua kajian ini adalah tidak sama apabila melibatkan jenis gigi yang berbeza serta populasi yang berbeza. Hal ini kerana kadar pemendapan dentin sekunder adalah tidak sama pada setiap jenis gigi serta populasi (Du et al. 2011; Erbudak et al. 2012).

\section{ANALISIS REGRESI LINEAR BAGI PENJANAAN FORMULA PENGIRAAN UNTUK MENGANGGAR UMUR INDIVIDU}

Analisis regresi linear dilakukan untuk membina formula pengiraan bagi menganggar umur individu. Sebanyak tiga formula pengiraan dijana masing-masing berdasarkan pramolar pertama pada arkus maksila $(14+24)$, arkus mandibel $(34+44)$ serta gabungan maksila dan mandibel $(14+24+34+44)$. Umur individu dijadikan sebagai pembolehubah bersandar dan PTR sebagai pembolehubah tidak bersandar dalam penjanaan graf regresi linear.

Tiga formula yang telah dijana daripada model regresi linear untuk menganggar umur individu bagi setiap kombinasi pramolar pertama iaitu maksila, mandibel serta kombinasi maksila dan mandibel. Dalam kaedah Cameriere, formula pengiraan pertama yang dijana berdasarkan pramolar pertama maksila mempunyai nilai $\mathrm{R}^{2}$ 0.37 dengan nilai ralat piawai anggaran (S.E.E.) 3.329 tahun. Seterusnya, formula kedua bagi pramolar pertama pada arkus mandibel pula menunjukkan nilai $\mathrm{R}^{2} 0.488$ dan nilai S.E.E. 4.143 tahun manakala formula ketiga yang dijanakan bagi kombinasi pramolar maksila dan mandibel menunjukkan nilai $\mathrm{R}^{2} 0.37$ dan nilai S.E.E. adalah 3.878 tahun (Jadual 3). Kajian oleh De Luca et al. (2010) yang menjalankan analisis PTR (nisbah kawasan pulpa kepada kawasan gigi) terhadap gigi kanin berupaya untuk menganggar umur individu yang telah meninggal dunia dan skop anggaran umur boleh dikecilkan lagi apabila melibatkan penanda morfologi yang lain seperti analisis tulang rangka dan tulang karpus. Anggaran umur berdasarkan pendekatan Cameriere bukan sahaja boleh digunakan pada gigi rangka manusia tetapi juga individu yang masih hidup. Dalam kajian ini, didapati daripada tiga formula pengiraan R2 bagi anggaran umur yang dijana, formula pramolar pertama pada arkus maksila adalah paling tepat kerana memberikan nilai R2 dan S.E.E. yang paling rendah (formula (i) Jadual 3).

Analisis regresi linear yang telah dilakukan oleh Cameriere et al. (2012) menggunakan gigi pramolar pertama dan kedua pada arkus mandibel untuk populasi Sepanyol menunjukkan julat nilai R2 adalah daripada julat

JADUAL 2. Nilai koefisien korelasi Pearson (r) untuk mengetahui hubungan antara umur individu dengan PTR (nisbah kawasan pulpa kepada gigi)

\begin{tabular}{lccc}
\hline Teknik pengukuran & Lokasi gigi & Koefisien Pearson $(\mathrm{r})$ & Nilai P \\
\hline \multirow{3}{*}{ Cameriere } & Maksila & -0.608 & 0.00 \\
& Mandibel & -0.699 & 0.00 \\
& Maksila+Mandibel & -0.608 & 0.00 \\
\hline
\end{tabular}


JADUAL 3. Formula pengiraan bagi menganggar umur individu mengikut jenis gigi pramolar pertama

\begin{tabular}{lclcc}
\hline Gigi/Kombinasi & $\mathrm{n}$ & Formula pengiraan & $\mathrm{R}^{2}$ & S.E.E ( \pm tahun) \\
\hline (i) Maksila & 79 & Umur $=33.74-132.0(\mathrm{PTR})$ & 0.37 & 3.329 \\
(ii) Mandibel & 57 & Umur $=39.83-161.0(\mathrm{PTR})$ & 0.488 & 4.413 \\
(iii)Maksila+Mandibel & 136 & Umur $=33.85-124.0(\mathrm{PTR})$ & 0.37 & 3.878 \\
\hline
\end{tabular}

$\mathrm{R}^{2}$ : coefficient of determination, S.E.E: Ralat piawai umur yang dianggarkan

0.69 hingga 0.75 bagi formula untuk satu jenis pramolar sahaja dengan nilai S.E.E. 7.42 hingga 7.99 tahun. Formula pengiraan bagi kombinasi semua gigi pramolar pertama dan kedua pula mempunyai julat R2 dari 0.79 hingga 0.86 dengan nilai S.E.E. 5.31 hingga 5.96 tahun. Oleh itu, nilai R2 dan S.E.E. yang diperoleh daripada kajian Cameriere et al. (2012) yang melibatkan populasi Sepanyol adalah lebih tinggi berbanding dengan nilai yang dijana daripada populasi Malaysia. Ini menunjukkan formula yang dijana daripada populasi Sepanyol tidak begitu tepat dalam menganggar umur individu kerana perbezaan antara umur sebenar individu dengan anggaran umur yang dijana daripada formula pengiraan adalah lebih besar berbanding dengan populasi Malaysia.

Selain itu, kajian anggaran umur menggunakan gigi kanin bagi populasi penduduk di India melalui teknik Cameriere yang dijalankan oleh Jeevan et al. (2011) mempunyai formula pengiraan yang berbeza iaitu lebih besar berbanding dengan kajian Cameriere et al. (2007) yang menggunakan gigi kanin pada populasi Kaukasia. Perbandingan terhadap populasi menunjukkan populasi penduduk di India menghasilkan anggaran umur paling tidak tepat diikuti dengan populasi Sepanyol dan Malaysia. Walau bagaimanapun, hal ini juga membuktikan bahawa setiap populasi harus mempunyai formulanya yang khusus agar dapat menganggar umur dengan lebih tepat. Tambahan pula, perbezaan formula juga boleh disebabkan oleh saiz sampel yang tidak sama serta ralat kepada teknik pengukuran. Selain itu, terdapat pelbagai faktor yang boleh menyumbang kepada perbezaan dalam penjanaan formula bagi menganggar umur individu seperti kepelbagaian jenis gigi bagi setiap individu, corak pemendapan dentin sekunder yang berbeza pada jenis gigi yang berbeza dan sudut antara alur sinar- X dengan filem (Cameriere et al. 2012).

\section{PURATA PERBEZAAN ANTARA UMUR SEBENAR DENGAN UMUR YANG DIANGGAR DARIPADA FORMULA YANG DIJANA}

Sebanyak 32 sampel gigi pramolar pertama dipilih secara rawak untuk menguji ketepatan kesemua formula pengiraan yang telah dijana. PTR bagi setiap jenis pramolar pertama diaplikasikan dalam formula pengiraan yang dijana. PTR bagi gigi pramolar pertama maksila diaplikasikan dalam formula pengiraan maksila, dan formula kombinasi kesemua pramolar pertama. PTR bagi gigi pramolar pertama mandibel pula diaplikasikan dalam formula mandibel, dan formula kombinasi kesemua gigi manakala PTR bagi kesemua gigi pramolar pertama diaplikasikan dalam formula kombinasi semua gigi. Jadual 4 menunjukkan hasil analisis purata perbezaan antara umur sebenar individu dengan umur yang dianggarkan menggunakan formula pengiraan masing- masing.

Apabila PTR bagi gigi maksila diaplikasikan pada formula maksila untuk penganggaran umur, didapati purata perbezaan antara umur sebenar dengan umur yang dianggarkan adalah sebanyak 2.781 tahun. PTR bagi gigi maksila juga diaplikasikan pada formula kombinasi kesemua gigi pula mendapati purata perbezaan sebanyak 1.670 tahun dengan umur sebenar individu (Jadual 4). Purata perbezaan bagi PTR gigi mandibel yang diaplikasikan pada formula untuk gigi mandibel adalah 2.103 tahun manakala mempunyai purata perbezaan sebanyak 3.316 tahun apabila PTR gigi mandibel diaplikasikan dalam formula kombinasi kesemua pramolar pertama (Jadual 4). PTR bagi kesemua gigi pula diaplikasikan dalam formula kombinasi kesemua pramolar dan mendapat purata perbezaan sebanyak 2.750 tahun berbanding dengan umur sebenar individu (Jadual 4).

Kesemua nilai daripada purata perbezaan menunjukkan bahawa anggaran umur yang didapati adalah hampir dengan umur sebenar individu iaitu pada julat perbezaan 1.670-3.316 tahun. Keputusan ini (Jadual 4) menunjukkan bahawa penggunaan formula kombinasi kesemua pramolar untuk diaplikasikan pada pengukuran PTR yang melibatkan gigi maksila merupakan anggaran umur yang paling tepat (purata perbezaan: 1.670 tahun) diikuti dengan formula mandibel yang diaplikasikan dengan gigi mandibel (purata perbezaan: 2.103 tahun). Ini diikuti dengan formula kombinasi untuk menganggar umur melibatkan kesemua gigi pramolar pertama (purata perbezaan: 2.750 tahun) adalah lebih baik daripada formula maksila yang diaplikasikan pada gigi maksila (purata perbezaan: 2.781 tahun). Akhir sekali, purata perbezaan yang paling berbeza adalah formula kombinasi yang diaplikasikan pada gigi mandibel (purata perbezaan: 3.316 tahun).

Sebanyak tiga formula pengiraan yang telah dijana bagi menganggar umur individu berdasarkan jenis pramolar pertama berbeza melalui model regresi linear iaitu:

Gigi premolar pertama $(14+24)$ : umur $=33.74-132.0 \times$ PTR; Gigi pramolar pertama (34+44): umur $=39.83-161.0 \times$ PTR; dan Kombinasi gigi pramolar pertama $(14+24+34+44)$ : umur $=33.85-124.0 \times$ PTR. 
JADUAL 4. Purata perbezaan umur sebenar dengan anggaran umur hasil daripada formula pengiraan

\begin{tabular}{ccc}
\hline Jenis gigi pramolar (PTR) & Formula & $\begin{array}{c}\text { Purata perbezaan antara umur sebenar dengan } \\
\text { anggaran umur (Tahun) }\end{array}$ \\
\hline \multirow{2}{*}{ Maksila } & Formula maksila & 2.781 \\
& Formula Maks+Man & 1.670 \\
Mandibel & Formula mandibel & 2.103 \\
& Formula Maks+Man & 3.316 \\
Maksila+Mandibel & Formula Maks+Man & 2.750 \\
\hline
\end{tabular}

Formula Maks + Man (Formula Maksila + Mandibel): Formula yang dijana hasil kombinasi kesemua gigi pramolar pertama (14+24+34+44), formula maksila: formula yang dijana daripada kesemua gigi maksila, formula mandibel: formula yang dijana daripada kesemua gigi mandibel. PTR: nilai nisbah kawasan pulpa gigi/kawasan gigi diukur pada jenis gigi melalui pendekatan Cameriere

Secara keseluruhannya, julat bagi purata perbezaan antara umur sebenar dengan umur yang dianggarkan adalah 1.670 - 3.316 tahun (Jadual 4). Walau bagaimanapun, kajian ini hanya melibatkan sampel gigi pramolar dan penganggaran umur individu daripada formula yang dijana akan menjadi lebih tepat jika melibatkan sampel manusia daripada jenis gigi yang sama.

\section{KESIMPULAN}

Wujudnya hubungan negatif antara nilai PTR dengan umur individu (koefisien korelasi Pearson: -0.608 hingga -0.699) berdasarkan pendekatan Cameriere pada populasi Malaysia. Ujian secara rawak dalam penentuan umur pula mendapati julat purata perbezaan antara umur sebenar individu dengan anggaran umur menggunakan formula yang dijana adalah 1.670 hingga 3.316 tahun.

\section{PENGHARGAAN}

Penghargaan diberikan kepada geran penyelidik GUP-2017054 dan GGPM-2017-085 yang membantu dalam kajian ini.

\section{RUJUKAN}

Aboshi, H., Takahashi, T., Tamura, M. \& Komuro, T. 2000. Age estimation based on the morphometric analysis of dental root pulp using ortho cubic super high resolution $\mathrm{Ct}$ (Ortho-Ct). Dlm Forensic Odontology, edited by Willems, G. Leuven: University Press. hlm. 199.

Agematsu, H., Someda, H., Hashimoto, M., Matsunaga, S., Abe, S., Kim, H-J., Koyama, T., Naito, H., Ishida, R. \& Ide, Y. 2010. Three-dimentional observation of decrease in pulp cavity volume using micro-CT: Age related changes. The Bulletin of Tokyo Dental College 51(1): 1-6.

Arora, J., Talwar, I., Sahni, D. \& Rattan, V. 2016. Secondary dentine as a sole parameter for age estimation: Comparison and reliability of qualitative and quantitative methods among North Western adult Indians. Egyptian Journal of Forensic Sciences 6(2): 170-178.

Cameriere, R., De Luca, S., Alemán, I., Ferrante, L. \& Cingolani, M. 2012. Age estimation by pulp/tooth ratio in lower premolars by orthopantomography. Forensic Science International 214(1): 105-112.

Cameriere, R., Ferrante, L., Belcastro, M.G., Bonfiglioli, B., Rastelli, E. \& Cingolani, M. 2007. Age estimation by pulp/ tooth ratio in canines by Peri-Apical X-Rays. Journal of Forensic Sciences 52(1): 166-170.

Chandramala, R. 2009. Application of Kvaal's technique of age estimation on digital panoramic radiographs. Dentistry 2: 142

Cunha, E., Baccino, E., Martrille, L., Ramsthaler, F., Prieto, J., Schuliar, Y., Lynnerup, N. \& Cattaneo, C. 2009. The problem of aging human remains and living individuals: A review. Forensic Science International 193(1): 1-13.

De Luca, S., Alemán, I., Bertoldi, F., Ferrante, L., Mastrangelo, P., Cingolani, M. \& Cameriere, R. 2010. Age estimation by tooth/pulp ratio in canines by Peri-Apical X-Rays: Reliability in age determination of Spanish and Italian medieval skeletal remains. Journal of Archaeological Science 37(12): 30483058.

Du, C., Zhu, Y. \& Hong, L. 2011. Age-related changes in pulp cavity of incisors as a determinant for forensic age identification. Journal of Forensic Sciences 56(s1): S72-S76.

El-Bakary, A.A., Hammad, S.M. \& Mohammed, F. 2010. Dental age estimation in Egyptian children, comparison between two methods. Journal of Forensic and Legal Medicine 17(7): 363-367.

Erbudak, H.O., Ozbek, M., Uysal, S. \& Karabulut, E. 2012. Application of Kvaal Et Al.'S age estimation method to panoramic radiographs from Turkish individuals. Forensic Science International 219(1-3): 141-146.

Jeevan, M.B., Kale, A.D., Angadi, P.V. \& Hallikerimath, S. 2011. Age estimation by pulp/tooth area ratio in canines: Cameriere's Method assessed in an Indian sample using radiovisiography. Forensic Science International 204(1): 209.e201-209.e205.

Limdiwala, P.G. \& Shah, J.S. 2013. Age estimation by using dental radiographs. Journal of Forensic Dental Sciences 5(12): 118-122.

Mjör, I.A. 2009. Dentin permeability: The basis for understanding pulp reactions and adhesive technology. Brazilian Dental Journal 20(1): 3-16.

Panchbhai, A.S. 2011. Dental radiographic indicators, a key to age estimation. Dentomaxillofacial Radiology 40(4): 199-212.

Rohaya, M.A.W., Hartini, I., Habibah, Y. \& Shahrul Hisham, Z.A. 2013. Cephalometric and malocclusion analysis of Kadazan Dusun ethnic orthodontic patients. Sains Malaysiana 42(1): 25-32.

Rus Dina, R.D., Shahrul Hisham, Z.A., Sahidan, S., Rohaya, M.A.W. \& Intan Zarina, Z.A. 2014. Molecular mitochondrial DNA and radiographic approaches for human archaeology identification. Sains Malaysiana 43(10): 1523-1535.

Ruzanna, A.K., Shahrul Hisham, Z.A., Rohaya, M.A.W., Shabnam, K. \& Sahidan, S. 2012. Characterization of 
mononucleated human peripheral blood cells. The Scientific World Journal 2012: 843843.

Sahidan, S., Shahrul Hisham, Z.A., Rus Dina, R.D., Rohaya, M.A.W., Intan Zarina, Z.A. \& Zaidah, Z.A. 2014. Haplogroup determination using hypervariable region 1 and 2 of human mitochondrial DNA. Journal of Applied Sciences 14(2): 197-200.

Sakhdari, S., Mehralizadeh, S., Zolfaghari, M. \& Madadi, M. 2015. Age estimation from pulp/tooth area ratio using digital panoramic radiography. JIDAI 27(1): 1.

Shabnam, K., Rohaya, M.A.W., Intan Zarina, Z.A., Zaidah, Z.A., Sahidan, S. \& Shahrul Hisham, Z.A. 2014. Differentiation capacity of mouse dental pulp stem cells into osteoblasts and osteoclasts. Cell Journal (Yakhteh) 16(1): 31-42.

Shahrul Hisham, Z.A., Sahidan, S., Rohaya, M.A.W., Siti Afeefah, M.Y., Intan Zarina, Z.A., Nor Hidayah, J.A.N., Nadiah, R.M.A. \& Zaidah, Z.A. 2009. Molecular gender determination of ancient human from Malay Peninsular. American Journal of Applied Sciences 6(10): 1770-1777.

Shahrul Hisham, Z.A., Mohd Faiz, E., Rohaya, M.A.W., Yousni, B. \& Sahidan, S. 2010. Profil aktiviti laktat dehidrogenase, asid fosfatase rintang tartat dan akalin fosfatase pada air liur semasa rawatan ortodontik. Sains Malaysiana 39(3): 405-411.

Tavakol, M. \& Dennick, R. 2011. Making sense of Cronbach's Alpha. International Journal of Medical Education 2: 53-55.

Verma, A.K., Kumar, S., Rathore, S. \& Pandey, A. 2014. Role of dental expert in forensic odontology. National Journal of Maxillofacial Surgery 5(1): 2-5.

Rus Dina Rus Din

Pusat Sains Kesihatan dan Gunaan

Fakulti Sains Kesihatan, Universiti Kebangsaan Malaysia

Jalan Raja Muda Abdul Aziz

50300 Kuala Lumpur, Wilayah Persekutuan

Malaysia
Siti Nur Zahidah Zahari, Liew Yi Ying \& Shahrul Hisham Zainal Ariffin*

Pusat Bioteknologi dan Makanan Berfungsi

Fakulti Sains dan Teknologi

Universiti Kebangsaan Malaysia

43600 UKM Bangi, Selangor Darul Ehsan

Malaysia

Rohaya Megat Abdul Wahab

Unit Ortodontik

Pusat Kesihatan Pergigian Keluarga

Fakulti Pergigian, Universiti Kebangsaan Malaysia

Jalan Raja Muda Abdul Aziz

50300 Kuala Lumpur, Wilayah Persekutuan

Malaysia

Zaidah Zainal Ariffin

Pusat Pengajian Biologi

Fakulti Sains Gunaan, Universiti Teknologi MARA

40450 UiTM Shah Alam, Selangor Darul Ehsan

Malaysia

*Pengarang untuk surat-menyurat; email: hisham@ukm.edu.my

Diserahkan: 24 Mei 2018

Diterima: 16 Januari 2019 